\section{Konfliktien pyörteissä}

Mikko Jakonen: Konflikti. Talous ja politiikka. Into, Helsinki, 2020, 392 s.

Sivistyssanakirjassa konflikti on yhteentörmäys, ristiriita tai selkkaus. Konflikti onkin kiehtova lähtökohta teokselle, joka käsittelee talouden ja politiikan välisiä jännitteitä. Konfliktin pääteesi kuuluu, että talouspolitiikka esitetään epäpoliittisena asioiden hoitamisena, vaikka ristiriidat ovat demokratian ydin. Kirjassa ei selkkauksia pelätä, vaan mennään niitä kohti.

Yhteiskuntapolitiikan tutkija Mikko Jakonen on aktiivinen yhteiskunnallinen keskustelija, joka taitaa politiikan teorian popularisoinnin. Viiteen osaan jakautuvan teoksen ensimmäisessä osassa kuvataan osuvasti, kuinka konfliktit paljastavat itsestään selviltä vaikuttavien asioiden jännitteet. Konfliktit ovat herkullisia, sillä ne sotkeutuvat toisiinsa ja luovat uusia konflikteja: talouspoliittiset linjanvedot eivät olekaan "parhaita ratkaisuja” vaan monisäikeisiä arvokonflikteja. Epäpoliittisilta vaikuttavat päätökset ovat tapahtumia, jotka avaavat mahdollisuuksia ajatella toisin.

\section{Talouspuheen konfliktit}

Kirjan toinen osa pureutuu taloustieteen konflikteihin sekä kamppailuun totuuksista. Pidin sitä kirjan kiinnostavimpana osana, sillä minuakin

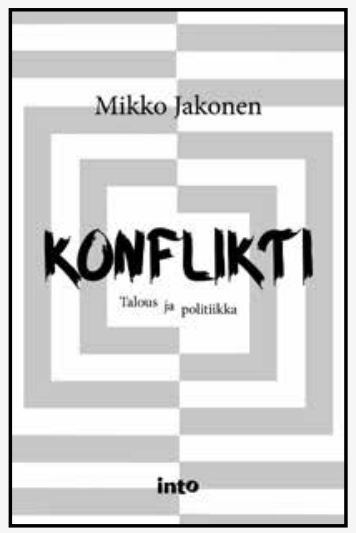

on mietityttänyt se, miksi vaihtoehtoisen talouspolitiikan teorioille ei tunnu Suomessa löytyvän sijaa. Valtavirrasta poikkeaviin näkemyksiin suhtaudutaan pilkaten tai kauhistellen, vaikka niiden esittäjällä ei olisi edes valtaa toteuttaa niitä. Talouspoliittinen keskustelu vaikuttaakin rakentuvan mustavalkoiselle asetelmalle, jossa kukaan järjellinen kansalainen ei kiistele valtavirtaa edustavien ekonomistien eli "talousviisaiden" kanssa, kuten Jakonen Twitterin suppeaa ekonomistijoukkua nimittää.

Jakonen esittää perustellusti miksi yksiääninen keskustelu taloudesta on demokratialle ongelma. Tunnistan ilmiön, mutta en ole aktiivinen sosiaalisessa mediassa, joten jäin kaipaamaan vielä tarkempaa analyysiä siitä, millaisista keskusteluista on kyse, miksi pienellä ekonomistijoukolla on valtaa, keitä he ovat ja mikä on heidän suhteensa yliopistoihin, puolueisiin tai esimerkiksi valtiovarainministeriöön. Tavoitan kuvauksen talouspuheeseen liittyvästä vallankäytöstä, mutta siitä jäin epävarmaksi, kuinka laajasta ilmiöstä on kyse ja mitä sille voisi tehdä.

Teoksessa toistui myöhemminkin erilaisissa yhteyksissä ajatus siitä, että me kaikki osallistuisimme sosiaalisessa mediassa poliittisiin kiistoihin. Jakosen näkemys ei vastaa arkista kokemustani, mutta sen sijaan toimittajat ja esimerkiksi Helsingin Sanomat tuntuvat tarttuvan hanakasti somessa käytäviin keskusteluihin ja jakavan niitä 
suuren yleisön tietoisuuteen. Olisikin kiehtovaa lukea lisää Jakosen analyysiä median roolista talouspuheessa. Myös talouspolitiikkaa historiallistavat osat olivat kirjan kiehtovinta antia, samoin taloustieteen sisäisiä kiistoja avaava pohdinta. Konfliktit, kuten Jakonen esittää, tarjoavat tässäkin tapauksessa välineitä ajatella asioita toisin.

\section{Uuden työn konfliktit}

Konfliktin kerronnassa on esseistinen ote, jossa kirjoittajan omat kokemukset ja havainnot yhdistyvät yhteiskuntateoriaan. Ote korostuu kolmannessa osassa, jossa käsitellään työelämän muutosta teollisesta työstä uuteen työhön eli jälkiteolliselle yhteiskunnalle tyypilliseen joustotyöhön. Alkuun työn muutosta kuvataan kirjoittajan omien matkakertomuksien kautta. Kertomuksissa havainnoidaan teollisuuden jälkeisiä maisemia kohtaamisilla niin japanilaisten pätkätyöläisten kuin amerikkalaisen petetyn keskiluokan kanssa.

Matkakertomukset sopivat teoksen luonteeseen, mutta jäin kaipaamaan niiden tiiviimpää yhdistämistä osion lopussa korostuvaan teoreettiseen keskusteluun prekarisaatiosta. Teoreettisen keskustelun yhteydessä on teräviä huomioita siitä, kuinka uuden työn yhteiskunnassa rakenteelliset ongelmat ilmenevät henkilökohtaisina patologioina. Puhuttelevaa on myös pohdinta nykytyöelämän vimmaisesta huippupuheesta, joka on ainakin yliopistolaisille tuttua. Rationalisointi- ja tehostamisprosessit kuvataan osaksi talouspoliittista agendaa, mutta jäin pohtimaan, kenen kanssa lopulta ollaan konfliktissa, mikäli niitä haluaa vastustaa. Huippuja haetaan erityisen innokkaasti vaikkapa Suomen Akatemiassa, mutta selkeää vastarintaa huippupuheelle ei ole yliopistoissa syntynyt. Jotkut tuntuvat jopa nauttivan oman erinomaisuutensa korostamisesta ja pelaavan uusien sääntöjen mukaan - etenkin jos sen myötä on tarjolla työtä ja rahoitusta.

Jakosen työelämäpohdintoihin on siis helppo yhtyä, etenkin kun työelämän muutosta kuvaillaan melko lavealla pensselillä. Kutsuva kuvaus kuitenkin särähtää vakaamman entisen ja prekaarin nykyisyyden vertailussa. Kärjistäen ku- vaus luo mielikuvan sotienjälkeisestä Suomesta paikkana, jossa kaikille riitti töitä ja niukkuudesta huolimatta elämä oli täynnä iloa eikä silkkaa kotiin tunkevaa työtä. Ehkä niinkin, mutta nostalgia jättää huomiotta sen, että sotienjälkeinen hyvinvointi ei jakaantunut tasaisesti. Etenkin maaseutua piinasi kausityöttömyys, johon ratkaisua haettiin työttömyystöistä eli niin sanotusta lapiolinjasta. Työvelvoite on siis osa suomalaisen työelämän historiaa, ei uusi ilmiö. Lavea kerronta jättää tulkintavastuuta lukijalle, joten oletan, että kirjoittaessaan pysyvistä työsuhteista ja asiallisista ylityökorvauksista "ennen" Jakonen viittaa melko lyhyeen ajanjaksoon ennen 1990-luvun lamaa.

\section{Politiikan konfliktit}

Konfliktin viimeisissä osissa käsitellään politiikkaa ja demokratiaa. Teemoihin palaaminen on perusteltua, sillä kirjassa pohditaan paljon uuden ekologisen ja tasa-arvoisen yhteiskuntamallin luomista. Politiikka-osiossa Jakonen pohtii kärjekkääseen sävyyn, kuinka valtio, puolueet ja ammattiyhdistysliike ovat hylänneet politiikan. Tarvitaan siis talouden ja politiikan välisen konfliktin uudelleenmäärittelyä eli joukkovoimaa, aktivismia, ihmisiä ja liikkeitä. Loppua kohden teos muuttuukin kutsuhuudoksi yhteiseen keskusteluun ja toimintaan.

Viimeiset osiot saivat minut mietteliääksi, etenkin Jakosen luoma kuva demokratian tilasta. Onko todella niin, että edustuksellinen demokratia on kyvytöntä tai halutonta vuoropuheluun yhteiskunnallisten liikkeiden kanssa? Tein Sipilän hallituksen kaudella kansanedustajahaastatteluita, mutta en tunnistanut niissä välinpitämättömyyttä kansalaisyhteiskunnan toimintaa kohtaan. Sen sijaan puolueet ja liikkeet tuntuivat olevan jatkuvassa vuoropuhelussa - konfliktissa sillä monet puolueet ovat syntyneet liikkeistä, ja puolueiden sisällä ja reunoilla on liikettä. Mikäli Jakonen viittaa vähäisellä vuoropuhelulla liian hitaaseen reagointiin käsillä olevaan ekologiseen kriisiin, niin se lienee totta, sillä edustuksellinen politiikka on myös poliitikkojen mielestä tuskastuttavan hidasta. 
Politiikan siilomaisuus ja hitaus vaikuttavat yhdistävän kriittiset yhteiskuntateoreetikot ja ajatuspajat: myös Sitra on viime vuosina peräänkuuluttanut viheliäisten ongelmien kuten ilmastonmuutoksen ratkaisua radikaalilla yhteistoiminnalla. Onkin hämmentävää huomata, että kriittisen yhteiskuntatutkimuksen tapa korostaa tietoperusteista päätöksentekoa kietoutuu jossain määrin yhteen sitralaisen konsulttipuheen kanssa. Jakonen kritisoi kutkuttavasti konsulttimaista uuskieltä, mutta vaikuttaa siltä, että tutkijat saavat olla itsekin tarkkana, että pohdiskeleva yhteiskuntateoria eroaa ajatushautomoiden raporteista. Yhteiskunnassa peräänkuulutetaan monesta suunnasta älyllisiä debatteja, mutta konflikti syntyy, kun selviää, millaisia konkreettisia visioita retoriikan takana piilee.

\section{Nuukailu yhteisresurssina}

Konflikti on tyyliltään esseistinen teos, ja se sopii pohdiskelevan kirjan luonteeseen. Tyyli tarjoaa vapauksia yhdistellä asioita, ilmiöitä ja aatteita toisiinsa luontevasti. Kirjaa lukiessa huomaakin tempautuvansa mukaan äärioikeiston identiteettipolitiikan sekä uusliberalismia kaikkialle tunkevan oikeiston pyörteisiin. Ajauduin välillä törmäykseen kirjan maailmanselityksen kanssa, sillä voimakkaita väitteitä oli toisinaan vaikea paikantaa. Kyse on ilmaisun tavasta: jos lauseissa ei ole selkeää tekijää, vaikuttaa siltä, että yhteiskunnassa asioita vain tapahtuu, aatteista irtisanoudutaan, keskusteluissa vähätellään ja ihmisiä tarvitaan mukaan toimintaan. Jostakin syystä juuri tämän teoksen kohdalla kaipasin täsmennystä siihen, kuka teki ja mitä - ja kenen pitäisi ajatella toisin.

Pienistä konflikteista huolimatta pidin Jakosen suorasta tavasta rakennella ajatusta radikaalista ekologisesta jälleenrakentamisesta. Väitteessä suomalaisen politiikan liiallisesta pragmaattisuudesta lienee vinha perä, ja huomaan usein itsekin olevani ikävystyttävän mielikuvitukseton - erityisesti silloin kun yritän visioida parempaa tulevaisuutta. Teoksen parasta antia olivatkin pohdinnat commonsseista eli yhteisresursseista sekä mahdollisuuksista hyödyntää niitä. Kirja saikin minut pohtimaan esimerkiksi suomalaista kirjastolaitosta uudella tavalla yhteisresurssina. Luulisi, että selkeät kaikkia palvelevat ratkaisut ylikulutuksen kitkemiseen löytäisivät paikkansa käytännöllisyyttä ja nuukailua arvostavassa yhteiskunnassa. 